\title{
A Japanese Winter Exercise
}

\section{Major K. Haushofer}

To cite this article: Major K. Haushofer (1913) A Japanese Winter Exercise, Royal United Services Institution. Journal, 57:419, 43-66, DOI: 10.1080/03071841309420055

To link to this article: http://dx.doi.org/10.1080/03071841309420055

$$
\text { 曲 Published online: } 11 \text { Sep } 2009 .
$$

Submit your article to this journal

Џll Article views: 5

Q View related articles $\sqsubset$ 


\section{A JAPANESE WINTER EXERCISE.}

\section{By Major K. Haushofer (Bavarian Army).}

(Translated, by permission, from the Militär Wochenblatt Supplement No. I of 1912).

Note.- The following translation illustrates admirably various tactical ideas prevailing in Japan as the result of experience gained in the war against Russia.

It likewise shows what valuable instruction can be acquired by means of exercises with small forces and partly improvised formations; and despite inclement weather conditions similar to those which usually prevail during the "winter training season" in Great Britain.

The criticisms by the author-an expert foreign observer-constitute a valuable addition to the instructive events which he narrates.-Ed.

THE winter exercises held by the I 6 th Division between the I2th and 16th February, were designed to include the following events:-On the first day, an encounter battle on the Tamamizu-Tanabe-Yawata road; on the second day, an attack by the Red Force on a Blue position in the hills; on the third day, retirement of Red across a river pursued by Blue; and on the fourth day, the active defence of the line of a river by Red. (See general map).

The situation on which the exercise was based was as follows :-

\section{GENERAL IDEA.}

A Blue army is holding the line Yokoogi-Multomachi.

A Red army is advancing via Fushimi against Blue.

\section{Special Idea. Blue.}

Morning of the 12th February.

The Blue commander has decided to retire to the heights of Otokoyama and Yamazaki and await the arrival of reinforcements before accepting battle.

Upon receiving information that a small force of the enemy is advancing down the Kizu Valley, the Blue commander detaches the force detailed below to protect the rear of his army:-

Ist and 2nd Battalions of the $9^{\text {th }}$ Infantry Regiment; and Squadron of the 2oth Cavalry Regiment; 2nd Battery of the 22nd F.A. Regiment; and two sections of the and Company of the 16th Pioneer Battalion.

This force, which is henceforward referred to as the Kizu detachment, had reached the bridge south of Yodo at 12 noon. Its commander had received information that the Red Force, which had hitherto been advancing on the right (east) bank of the Kizu, had reached the neighbourhood 
of Tamamizu, and was preparing to cross to the left (west) bank. The inhabitants reported that the Yawata-Matsui road was passable for field artillery.

\section{Special Idea. Red.}

The Red Kizu Detachment (as below) had received orders to operate against the rear of the Blue army; it had advanced on the cast bank of the river Kizu as far as Tamamizu, where it had crossed to the west bank on the rath February. The crossing had been completed by noon. The Asasano-Matsui-Yawata road was reported to be passable for field artillery.

Ist and and Battalions of the 53rd Infantry Regiment.

Half the ist Squadron of the 2oth Cavalry Regiment.

rst Battery of the 22nd F.A. Regiment.

One section of the 2nd Company of the I6th Pioneer Battalion.

The total forces engaged in the exercise were, therefore, quite small. There were altogether two regimental staffs, four infantry battalions, two cavalry squadrons, two batteries of field artillery, one company of pioneers and eight machineguns; second-line transport was represented by detachments of A.S.C.; all units were at war strength, ${ }^{1}$ with their full allowance of pack ammunition.

The Directing Staff consisted of General Oi, commanding the Igth Infantry Brigade, and his two staff officers; in addition the I6th Division was given its "I b"* General Staff Officer. My Austrian friend, Captain von Winternitz, and I were attached to the I6th Division. On the 12th February the Directing Staff left Kioto for the mancuvre area.

All officers who were not absolutely required for training the recruits in the garrisons took part in the exercise, and were employed as umpires, compensation officers, to replace casualties among the commanders, or as spectators.

The weather was slightly frosty; the sky was generally clear and the wind keen; these conditions continued almost till the end of the exercise, but at noon on the I 5 th there was a blizzard, which was followed by a change of the weather.

The four days were utilized to the very utmost, having regard to the limits imposed by the physical endurance of the troops; the manouvre area was comparatively small, but it was well selected and afforded plenty of scope for interesting situations, which were exploited to the utmost by the manœuvre scheme. The result was to give the older men of the division and the majority of the officers a thorough "Refresher," in the middle of the winter, without interfering appreciably with the training of the recruits.

1 In order to bring units up to war strength some reservists were called up to each regiment from the place at which it was stationed.

* The expression "I b" is used in the German Army to designate one of the two officers of the ist (General Staff) Section of an Army Corps Staff.-Ed. 
In order to reach the places of assembly laid down in the scheme, the infantry had to proceed by route march $12 \frac{1}{2}$ miles from Fushimi, nine miles from Nara and $12 \frac{7}{2}$ miles from Otsu. This is in accordance with the approved Japanese tradition of taking the edge off the marching powers of the troops before the mancuvres begin, in order to test their energy and capacity for endurance. ${ }^{1}$

At 12.30 p.m., by which time the concentration had been completed, the troops had rested, and were ready to move off. The situation was then as portrayed by the following order :-

RED.

\section{DETACHMENT ORDERS.2}

Tamamizu, I2th Feb. 12 noon.

Order of March.

Independent Cavalry.-Ist Squadron 2oth Cavalry Regiment.

Advanced Guard.-Ist Battalion of 53rd Infantry Regiment (less Nos. 3 and 4 companies); four mounted men; one section 16 th Pioneers.

Left Flank Guard.-2nd Battalion 53rd Regiment (less No. 2 company); two machine-guns.

Main Body. -Nos. 3 and 4 companies Ist Battalion 53rd Regiment; rst Battery 22nd F.A. Regiment; No. 2 company ind Battalion 53rd Regiment.
I. No news of enemy.

2. The detachment will march to Yawata, towards which place the independent cavalry advanced at 10.30 a.m. this morning to reconnoitre.

3. The infantry point of the advanced guard will move off at 12.30 p.m. along the Tanabe-Yawata road upon Yawata.

4. The left flank guard will move off at the same time as the advanced guard and proceed from Tanabe, via Matsui and Uchisato to Yawata.

5. The main body will move off at 12.30 p.m. from the centre of Tamamizu village.

6. Second-line transport will follow the main body at $i, 100$ yards distance.

7. The G.O.C. will ride at the head of the main body.

Note.-No infantry may cross the railway north of Tanabe before 2 p.m.

Dictated to commanding officers at Tamamizu.

1 Thus, for example, the inspection of companies in tactical training is usually arranged as an incident in a 25 mile march.

2 For Director's criticism on these orders see page 59--Ed. 
The Blue commander had likewise resolved to advance. His orders were that the advanced guard should start at $12.3^{\circ}$ for Tanabe via Yawata, the main body following at a distance of 770 yards. On reaching Yawata a flank guard consisting of two companies was to diverge from the main body and move via Matsui on Takigi.

\section{NARRATIVE OF THE OPERATIONS.}

The Independent Cavalry of the opposing sides, having been allowed to move off at 10.30 a.m., came in contact between Yawata and Osumi.

The Red advanced guard, which I accompanied at the commencement of the day's operations, sent out some infantry patrols at the double on a broad front to prevent the hostile cavalry from approaching within view. A little after 2 p.m., the point of the Red advanced guard came in contact with the Blue cavalry on the narrow plateau between 200 and 500 yards south of Asasano; the Red advanced guard hastened to deploy, and occupied a trench extending on either side of the road, 500 yards south of Yawata; from this position it was able to open an effective fire against the Blue advanced guard, which was debouching somewhat carelessly from Yawata.

Some weak flank guard detachments and patrols were engaged a little farther to the east, in an independent struggle for the river dyke, which is as much as 30 feet high in some places.

The road leading through Yawata was in such bad condition that some pioneer work was necessary before the Blue guns could get into action, which they finally did under fire of the guns and advanced guard of Red, in a position on the south-west border of Yawata (which, in real war, not a man would have reached alive). An encounter battle now commenced.

The energetic Blue commander quickly deployed his main body and sent it forward through the fields south-west of Yawata; meanwhile Red advanced by his left between Osumi and Matsui; the infantry, moving in close formation, sank deep in the marshy rice fields, and at the same time came under fire from the Blue machine-guns.

Great effect is allowed in Japan to surprise fire by machineguns from a flank, on account of the general confusion which fire of this sort was found to produce during the late war.

The position of Red at 3.30 p.m. when "Stand Fast" was sounded, was by no means favourable, although they had established a strong firing line along the embankment on which the road is carried to the east of Matsui.

At 5 p.m., after a long conference, operations were resumed. Red retired via Tanabe; Blue pursued half-heartedly and allowed 
themselves to be checked by fire at the embankment 200 yards south of Asasano; they halted again at the railway north of Tanabe, and at a place where an embankment is carried over the road at the latter place. The greatest eagerness in the pursuit was shown by the Blue battery commander with his mounted party; the machine-guns followed him at a rather slower pace. It was not until the evening that Blue halted at the embankment south of Tanabe in accordance with orders received from Army Headquarters.

Red had fallen back to Kodo, where they were turning to face their enemy, when the latter desisted from the pursuit. The Red commander had just given orders for his force to occupy close billets, in immediate readiness for action, when he received information from his army commander that he was going to begin the attack on the Blue Army on the 13th, on which day his left flank would move against the Mino Hill south of Yawata; and that the task for the Kizu Detachment was to drive back the Blue troops opposed to them, and then to co-operate on the extreme left flank of the Red Army's attack.

It was at first proposed, in pursuance of this order, to gain possession of Tanabe by a surprise attack in the darkness, but the patrols, which had been gradually working their way round the enemy's thin screen of posts, reported that neither Tanabe nor Takigi were occupied, and that the Blue outpost line was really much farther to the north, south of Asaoka and Asasano. The Blue detachment had received news after the action, from the 16th Division (on the right flank of the Blue Army) that it was falling back that very night to take up a defensive position south of Yawata. Shortly afterwards the following extract from Blue Army Orders was received, dated 12.30 p.m. :-

" I. On the 1 $3^{\text {th }}$ inst., the I6th Division will occupy the line from (right flank) hill 880 yards south of Minoyama -Village of Minoyama-Hill Otokoyama; on the 14th this division will again advance to the attack.

" 2. The Kizu Detachment will to-night occupy a position to cover the retirement of our main army; early tomorrow it will move to join the right wing of the 16th Division, and will entrench itself there, facing east."

The effect of these orders was that Red was only followed up by a portion of the Blue Force as far as the dyke south of Tanabe, where a false outpost line, which deceived Red for a time, was taken up by cavalry and patrols. Judging rightly that the first task was to gain time to fall back towards the north-west, the Blue commander now issued the following orders :- 
BLUE.

DETACHMENT ORDERS.

$$
\text { Asaoka, 12th Feb., 6.30 p.m. }
$$

I. The enemy has been driven back through Tanabe, and has taken up quarters for the night at Kodo. Asaoka.

2. Our detachment is quartered to-night in and around

3. The Ist Battalion 9th Infantry Regiment will furnish the outposts; reserve will be at Asasano; right flank will extend to the tea-plantation $\mathbf{7 7 0}$ yards south of Asaoka and the western slope of the hill at that place; left flank will be at the ford by the gap in the dyke opposite Mizushi, and will guard by frequent patrolling against any movement from the direction of Tanabe.

4. The main body will occupy close billets as under :-

Staff, machine-guns, 2nd Battalion of 9th Regiment, less No. 2 company at Asaoka; No. 2 company gth Regiment at East Ozumi; No. 2 squadron 2oth Cavalry Regiment and No. 2 company 16th Pioncers at West Ozumi; and Battery 22nd F.A. Regiment at Matsui.

Major T. will be commandant of Asaoka. Asaoka.

5. The alarm post will be in the fields south-east of

6. Rations will be issued from the wagons of the secondline transport (Grosse Baggage).

7. I shall remain at Asaoka, where orders will be issued at 9 p.m.

By 9 p.m. the troops on both sides had received their evening issue of supplies (or the amount required to complete it) and had turned in under the protection of their outposts, who were kept busy all night.

The commander of the Red Kizu Detachment issued the following orders for the 13th February :-

RED.

\section{ORDERS FOR THE KIZUGAWA DETACHMENT.}

Headquarters, Kodo, I2th February, 9 p.m.

I. The foremost protective detachments of the enemy opposed to us, are on the line of the high river bank south of Asasano-Asaoka. The main body of the enemy has fallen back and apparently intends to resist our advance in the hills at, and to the north of Minoyama.

The Kizugawa Detachment will to-morrow advance further along the left bank of the Kizu. 
2. To-morrow (1 $3^{\text {th }}$ February), the enemy will accordingly be attacked afresh; after defeating him, the detachment will establish touch with the Red main body.

3. The and Battalion 53rd Regiment, less two companies, will occupy the railway embankment north of Tanabe at 5 a.m. to-morrow; the machine-guns will accompany this battalion.

4. At the same hour the ist Battalion 53rd Regiment and two companies of the and Battalion 53rd Regiment, under the command of Major F., will be assembled north of Tanabe.

5. At 5.30 a.m. the battery will be "at the north of Tanabe" (by this was meant in action at the northern end of the village); one section of pioneers will accompany the battery.

6. The cavalry squadron will endeavour to reconnoitre along the left bank of the Kizu, and will cover our right flank.

7. Communication is to be established from Tanabe vici Nagaike to the road leading from Nara.

8. Second-line transport will remain till midday to-morrow on the right bank of the Kizu near Tono, to be halted in order of units as given in the order of battle.

9. I shall be at the cross roads in the centre of Tanabe at 5.30 a.m. ${ }^{2}$

The intentions of Blue were also modified in many respects. The original intention had been to move off quiclily to the north-west an hour before daybreak, and then to talse up a position for a delaying action in the neighbourhood AsaokaOsumi, the rearguard remaining south of Asasano; finally, it was decided to fall back on the heights 200 yards south-east of Minoyama, and to hold on there, linking up to the $16 \mathrm{th}$ Division. With this object, orders were issued at 2 a.m. on the 13th February that the battery was to fall back through Matsui and was to be formed up at $5 \mathrm{a.m}$. on the hill 880 yards north-east of Nagao; the and Battalion gth Infantry Regiment was to be at $5.20 \mathrm{a} . \mathrm{m}$. at the pond 500 yards north-east of Nagao; and the Ist Battalion gth Infantry Regiment was to be at 5.40 a.m. at the ponds 660 yards south of Minoyama (see map). One company of each battalion was to be left behind to mask the retirement and to afford some support to the cavalry which was going out to reconnoitre.

Blue carried out his retirement on to the selected position with great skill, and succeeded in completely hoodwinking the enemy ${ }^{2}$ the heights south of Matsui were found to provide good positions for rearguard actions.

The Red commander, unaware of the retirement of Blue, kept four of his guns in action to the west and two to the east

1 Unfortunately, by order of the Directing Staff, all operations were postponed till two hours later than the times prescribed in the orders.

2 See Director's criticisms on page 59.-Ed.

VOL. LVII. 
of Tanabe; his remaining troops he kept in the positions laid down by the orders, up to 7 a.m., without having been able to decide on any definite action. He then advanced astride of the road, and was enticed by the Blue rearguard, which played the rôle of a delaying force with consummate skill, into the country south-west of Matsui. Here all touch was lost with the Blue troops, who vanished suddenly and completely. At this juncture, Red received information that there was a strong Blue position north-west of Minoyama; and, further, that the advanced troops of the Red main body (which was now moving to the attack) would not appear north of

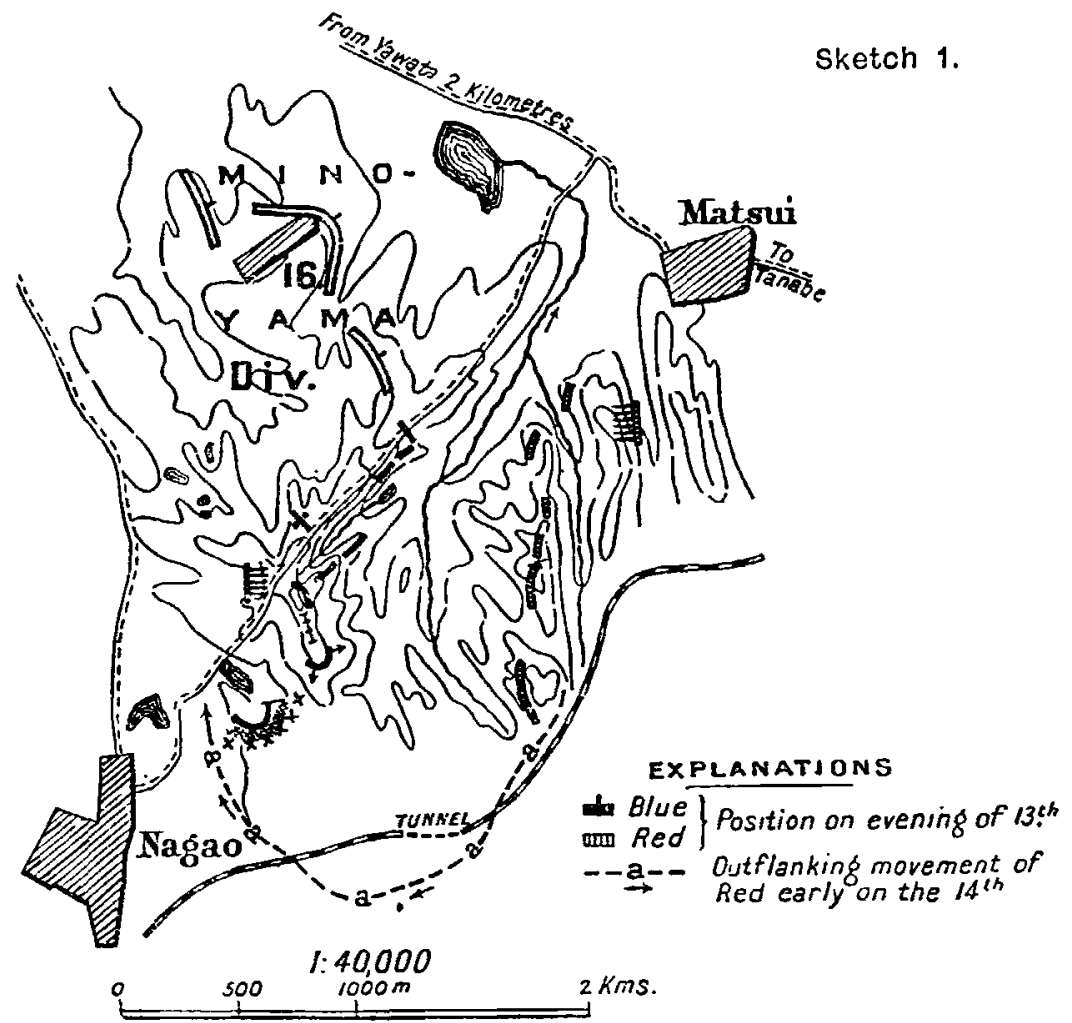

Matsui before 4.30 p.m. The Red commander realized, therefore, that he must proceed with caution in regaining touch with the enemy who had so mysteriously disappeared; meanwhile, he took steps to secure his position at Matsui and on the ridge south of that place, facing towards the west. (See sketch).

In the meanwhile, we spectators had made a detour, under the guidance of a General Staff Officer, and had reached the new defensive position of the Blue detachment. The ground, 
which was the scene of the ensuing operations, presented all the difficulties of mountainous country, though the actual altitudes above sea level were relatively small; it bore a striking resemblance, as was more than once observed by the Japanese officers, to the battlefield of Yang-tzu-ling in the Manchurian mountains.

During our ride we saw the Red advanced guard regain touch with the enemy; in so doing it was on one occasion much exposed to fire from the strong Blue position. The Red infantry patrols were soon busily engaged, and worked well. The heavy ground presented great difficulties to the advance of the guns; the artillery reconnoitring parties selected a position on the hill $55^{\circ}$ yards south-west of Matsui, but before it could be occupied the pioneers had to make a track over 200 yards of difficult ground; when this had been done the position was certainly an excellent one for artillery.

The Blue defensive line, which we reached about noon, by way of a steep narrow valley, was supposed to constitute the extreme right of the division on the right flank of the Blue Army. The front, which was about $\mathrm{I}, 540$ yards in extent, was only occupied, in the first instance, by one battalion of infantry, four machine-guns and one battery; the latter was employed in dispersed sections, but was kept under one control.

There was a double system of telephone communication between the various command posts and intelligence collecting stations (Meldestellen); and also to the advanced posts, to the commander, and to the reserve. The strength of the last named was one battalion; it was at first judiciously stationed in rear of the right flank, but later, in view of the enemy's preparations for a strong frontal attack, it was moved to a position in rear of the centre.

Blue were allowed plenty of time to strengthen their position; they were thus able to dig deep trenches, and to construct command posts, gun emplacements, covered communications, screens and dummy trenches; wire entanglements and abattis of pointed bamboos (the latter as dangerous in peace as in war) were also constructed on a large scale. By 3.30 p.m. the defensive position had become a perfect specimen of the art of field fortification; the work had been well executed, and the cover provided was good and substantial. Nevertheless, taken as a whole, the position suffered from the defect that the flank was too far advanced. In spite, therefore, of all the local strength afforded by the wire entanglements and pointed bamboo stakes the flank was unduly exposed to an enveloping movement.

The effects of the orders issued by the Red commander for the further operations that afternoon began to be visible about $3.20 \mathrm{p.m}$. These orders were as follows :- 
RED.

ORDERS FOR THE KIZU DETACHMENT.

Hill one kilometre south of Matsui, 13 th February, 2 p.m.

I. The enemy is occupying a strong position on the Matsui-Nagao road extending for about 440 yards on either side of the column. Some reserves are in the neighbourhood of the pond $55^{\circ}$ yards north of Nagao. The positions of his defences and outposts have not yet been precisely determined.

2. To-day the detachment will maintain its present position, in rear of which the troops will bivouac. We will await the advance of our main army (which is to engage the cnemy to-morrow) and then attack at daybreak to-morrow.

3. The and Battalion 53rd Regiment (less one company) will advance on both sides of the valley and make good the ridge.

4. The ist Battalion 53rd Regiment will hold the line from the mountain with the pinewood as far as the railway culvert near the tunnel.

5. The cavalry will advance towards Matsui in the evening and will establish touch with our main army, which is advancing north-east of that place.

6 The ist Battalion 53rd Regiment will protect the artillery position and bivouac.

7. The section of Pioneers is placed at the disposal of the Ist Battalion 53rd Regiment, with which it will bivouac.

8. The machine-guns will remain in their present position.

9. Supplies are being assembled at Matsui whence they will be sent up to the troops. Separate orders are being issued on this subject.

10. My position is at the bivouac of the Ist Battalion 53rd Regiment. Issue of orders will be at 9 p.m.

The first perceptible result of these orders was that between 3 and 3.30 p.m., two or three Red companies advanced in the valley and along its northern edge against the weak spot at the north-east wing of the Blue position, and proceeded to outflank and enfilade a very badly-sited fire trench. These companies had crossed 660 yards of extremely difficult ground in a remarkably short time; they were now taken in flank by the enemy's guns, and, at the same time, were engaged by his reserve which had hitherto been stationed in rear of his right flank; they were therefore compelled to retire, but their daring advance, taken in conjunction with the entrenching work which was being carried out by Red in front of the position, had the effect of drawing Blue's attention more towards his centre, in rear of which he now stationed his reserve.

In the later part of the afternoon the Blue commander came to the conclusion that no fresh developments were to be expected 
on the $13^{\text {th }}$ February, and at 5 p.m. he issued orders for the troops to bivouac on the position.

Meanwhile the attacking side had been carefully entrenching a position in front (north-west) of the bend of the railway; the intention was, apparently, to deceive the enemy as to the real objective of the attack; to occupy the position with the minimum number of troops, allowing the remainder to rest; and at daybreak to advance across some very difficult ground along the railway and thence against Nagao, in order to envelop the extreme right wing of the Blue Detachment.

The activity displayed by Red in front of the position naturally had the effect of making some action in this quarter appear probable. Blue fell into the trap, but at the same time advanced a portion of his infantry line during the night, so that, in the morning, Red found the enemy in a different position from the one that had been reconnoitred the previous evening. ${ }^{1}$

The Director was justifiably proud as he showed me over the Red entrenched position. The work had been executed with extraordinary thoroughness in a remarkably short time; the trenches were well sited and every contingency had been provided for. The number of troops required to occupy the position had been reduced to a minimum; the remainder were accommodated in bivouacs nestling into folds of the ground in rear of the position. There was a well-equipped observing station, with telephone wires leading in all directions, where orders were being quietly given out for the next day's operations.

The orders in question gave a description, as full as was possible, of the enemy's position, and dealt with the question of establishing communication with the left wing of the Red Army; they then continued as follows :-

"The Detachment will to-morrow deliver an enveloping attack against the enemy's right flank.

"The 2nd Battalion 53rd Regiment, with the machineguns, will advance at $5 \cdot 30$ a.m. to-morrow across the valley, and will draw fire from the position, keeping the latter under its own fire, and endeavouring to attract as large a number as possible of the enemy's troops, to the front of the position; a detachment will attempt to capture the enemy's battery.

"The Ist Battalion 53rd Regiment, with one section of the Pioneers, will move at 5 a.m. by the valley east of Nagao, so as to outflank the enemy's right and attack him in rear.

"Two companies of the 2nd Battalion 53rd Regiment will follow in rear of the Ist Battalion and will be at my disposal.

"The cavalry will advance beyond Nagao and reconnoitre in front of our left flank.

1 See under (b) of Author's criticisms.--Ed. 
"The artillery will open fire at daybreak (as soon as the infantry attack begins) against the enemy's right wing and against his guns." 1

From 4 to 4.30 a.m. On the I 4 th February patrols could be seen working actively before the front and left wing of the Blue position. Nothing else was visible, and the enveloping attack, which moved skilfully and silently across country, was unperceived; the proper working of the patrols in accordance with active service conditions was ensured by the presence amongst them of a number of young umpires.

Blue was fully aware of the weakness of his right wing, and had spared no pains to strengthen it; nevertheless at 5.30 a.m. on the 14th February the Red attack, advancing along the valley of Nagao (see sketch 1 . a-a-a) effected a complete surprise, and brushed aside all attempts at resistance. (The eastern sky was light at this time, but the lower ground was still wrapped in darkness). Blue had altered his line of defence in the night and had pushed out two companies of infantry and some pioneers some 200 yards to a small knoll which was favourably situated for defence.

This unexpected alteration in the position caused Red some delay ; the short burst of firing gave a general alarm, and the cohesion of the attack was destroyed. The Red attacking force encountered the Blue reserve, which had been hurriedly brought up, near the four small ponds on either side of the road 500 yards north-east of Nagao; hand to hand fighting would now have taken place right in the Blue artillery position had not the Directing Staff put an end to what had become an impossible situation.

Information was now conveyed by the Directing Staff to the Red commander that his main army was retiring, and that its left wing would be occupied till the morning of the $1^{\text {th }}$ in crossing to the eastern bank of the Kizu River near Kamitsuya. The Kizu Detachment was to withdraw forthwith to the ground south of Terada (on the eastern bank of the Kizu River) covering the retirement of the left wing of the army and securing its left flank. (See general map).

Red were thus unable to profit by the advantage which they had just gained, though their success assisted them in the difficult task of breaking off the engagement. They retired, showing their teeth more than once, across their position of the day before, through Tanabe, to the fords of the Kizu, south of Tono and Mizushi.

Blue now gained a little breathing space, and was in a position to comply with an order received from his main army, which read as follows :-

"The Blue Army will reply to the Red attack by a counterattack on the morning of the 14 th; with this object all available

1 See Director's criticisin quoted on page 60.-Ed. 
forces will be set in motion simultaneously. The intention is for the army to cross to the right bank of the Kizu at and near Kamitsuya about the afternoon of the $15^{\text {th }}$.

"The Kizu Detachment will forthwith drive back the enemy opposed to it, and will cross the Kizu River early to-morrow near Tono. It will then advance through Terada with the object of facilitating the passage of the river by the main army."

In accordance with these instructions Blue immediately gave orders for a pursuit. Three columns were formed, but they took a long time to get off and failed to co-operate. The cavalry and one company of infantry moved out some way to the south across the Fujisaka-Tanabe road. Red's retirement was, therefore, not closely pressed, and at Matsui, Asaoka, and Tanabe good opportunities presented themselves for counter strokes against the pursuing force; by these means Red gained time to draw off towards Tono and to cross the river.

The River Kizu was forded by the main body and the artillery south of Tono, and by the rearguard between Asasano and Mizushi. This was the first occasion on which troops had forded the river, and the achievement was only rendered possible by the unusually low level of the water. The actual depth in the rapid part of the stream was not more than 25 to 27 inches at the ford, but the bottom was partly mud and sand and partly loose boulders. A careless step plunged a man up to the chest in the ice-cold water. The waves surged over the guns more than once. The pressure of the current was considerable, and the main branch of the river was quite I 10 yards wide.

The fording of this river in the middle of winter, as an incident in a tactical exercise which had involved at least a third of the troops bivouacking in the open, must be regarded as a notable achievement. The chief difficulty for the vehicles, in addition to the steepness of the banks, was a deep channel which runs along the eastern shore; but all obstacles were easily overcome.

The dykes on the east bank of the Kizu afforded Red a strong position; just south of Tono these dykes receded, thus enabling a battery to be brought into action. In this position Red was finally able to check any further pursuit. As, however, the Red outpost line was now strongly established on the line of the river, it was no longer possible for the Blue cavalry and infantry patrols to cross the stream by daylight.

Leaving the battery in its position, for the time being, Red now entrenched himself in a well-chosen position near Terada. (See sketch 2). The position extended from that place, which formed a point d'appui for the western flank, into the hills; the front was about 2,650 yards and was occupied by seven companies, eight machine-guns and six field guns; five companies 
and the pioneers were held in reserve. The Ist (skeleton) Battalion of the Ist Regiment, which had arrived at Hirakawa, was placed at the disposal of the Red commander.

The Blue Force, which had reached the neighbourhood of Tanabe, was likewise reinforced by the ist Battalion of the 22nd Regiment, which had taken up quarters for the night at Asasano. At $4 \mathrm{p} . \mathrm{m}$. the Blue commander gave orders for the troops to occupy close billets in Tanabe. Outposts were pushed out as far as the left bank of the river, and touch was gained with the reinforcements at Asasano.

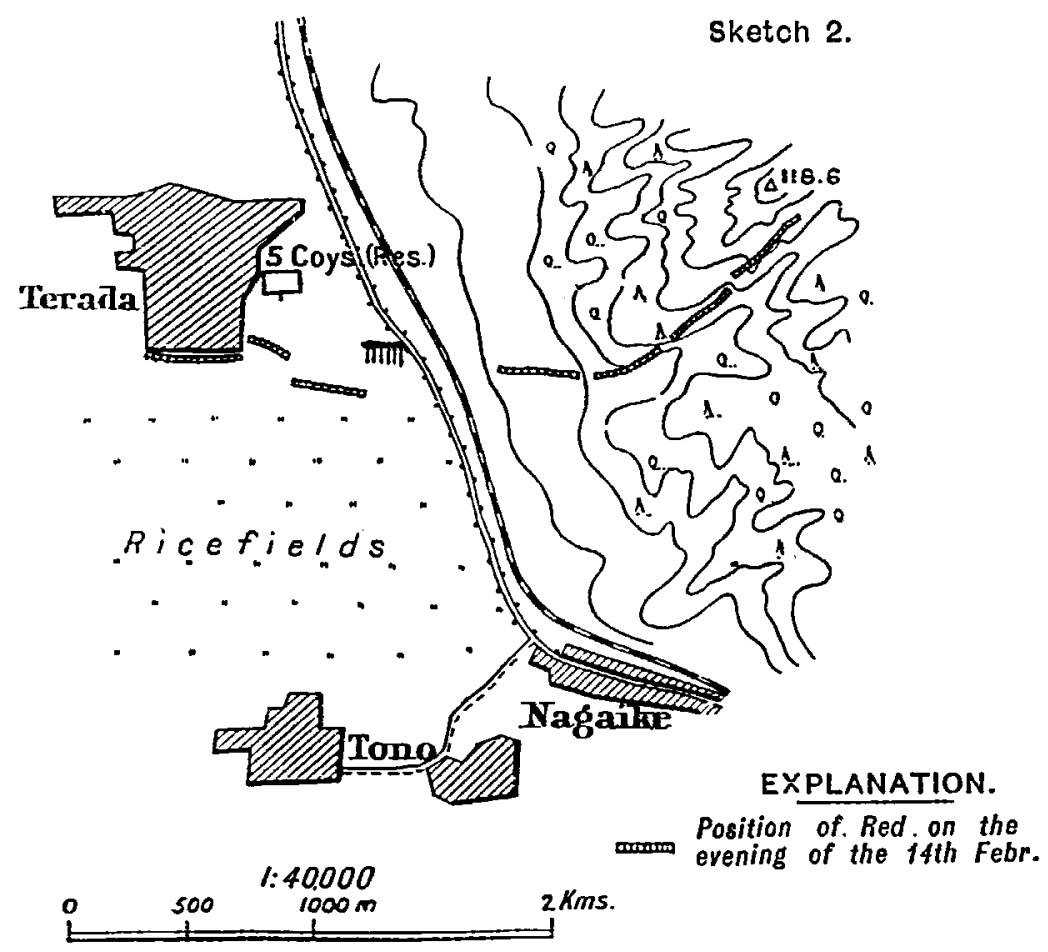

The Blue patrols had ascertained that Terada was still occupied by the enemy, and that hostile detachments were at Tono and Biwansho. The extreme flanks of the Red outpost line were located at Asajuroku and Mizushi. The Blue commander decided to cross to the eastern bank and attack the enemy early on the $15^{\text {th }}$; orders were issued for the assembly of the Blue troops at 4.30 a.m. at Tanabe and Takigi.

The Red Force finished entrenching by 6.30 p.m., and the troops went into close billets at Terada. An outpost company was pushed forward to Tono and another to Nagaike to watch the line of the Kizu. The Red patrols had found it impossible to cross the river in the afternoon, but it was estab- 
lished with the aid of telescopes from the hills near Terada that the Blue troops had entered Tanabe, but had not emerged from that place.

The Red commander, therefore, issued the following orders for the next day's operations :-

RED.

Headquarters, Terada, I4th February, 9 p.m.

I. No further news of enemy. The Ist Battalion ist Regiment has been placed under my orders.

2. The Detachment will to-morrow hold its present position in order to cover the retirement of the main army.

3. The cavalry squadron will move off at $4 \mathrm{a} \cdot \mathrm{m}$. to-morrow and, in co-operation with the outposts, will secure the passages of the river between Mizushi and Asajuroku, and establish communication with the main army, via Tsukahara.

4. The outpost companies will fire vigorously on any Blue troops attempting to cross the river. If compelled to retire by superior forces, the right outpost company will fall back first of all to our right flank, and then to the reserve; the left outpost company will fall back to the left flank of the position.

5. At 5 a.m. to-morrow the outposts will re-occupy their day positions. The O.C. Ist Battalion 53rd Regiment will resume command over his outpost company as soon as the latter falls back from the line of the river.

6. The Ist Battalion Ist Regiment will be assembled at 5 a.m. near the reserve.

7. The baggage will be formed up at 6 a.m. in column of route, head at South-Hirono.

8. I shall be with the reserve after 5 a.m.

At daybreak on the $15^{\text {th }}$ February Blue endeavoured to ford the river in two groups, south of Tono and near Asajuroku. It was, however, 6 a.m. before the first troops crossed; endeavours made at 4 a.m. met with no success as the conditions had altered and the river was too vigilantly guarded.

The Blue battery, which had come up to the river dyke south-east of Biwansho, was caught in a helpless situation by the fire of a company of Red infantry on the north-east bank, and was put out of action before our eyes. It was not possible for the battery to open fire rapidly on the narrow summit of the dyke with the teams in the intervals between the guns; the infantry escort remained under cover instead of replying to the enemy's fire. The group which was intended to carry out the secondary attack failed in its task, and exposed itself to unnecessary losses.

Meanwhile, however, the larger Blue group had forced a passage opposite Nashima in dashing style, wading through comparatively deep water and driving off the enemy's outposts 
at that point. This success compelled the remainder of the Red outposts, who had hitherto held their ground, to fall back from the line of the river.

By 7 a.m. Blue had obtained possession of Nagaike and Tono as points $d$ appui for a further advance. The battery was brought into action on the river dyke, near the road, to the south of Tono; the northern edge of Tono and a temple north-east of that place were occupied by two companies of infantry and by the pioneers, who had crossed with the guns.

The intention of the Blue commander was to attack through the wood with his right wing; with this object he organized his troops as shown in the sketch.

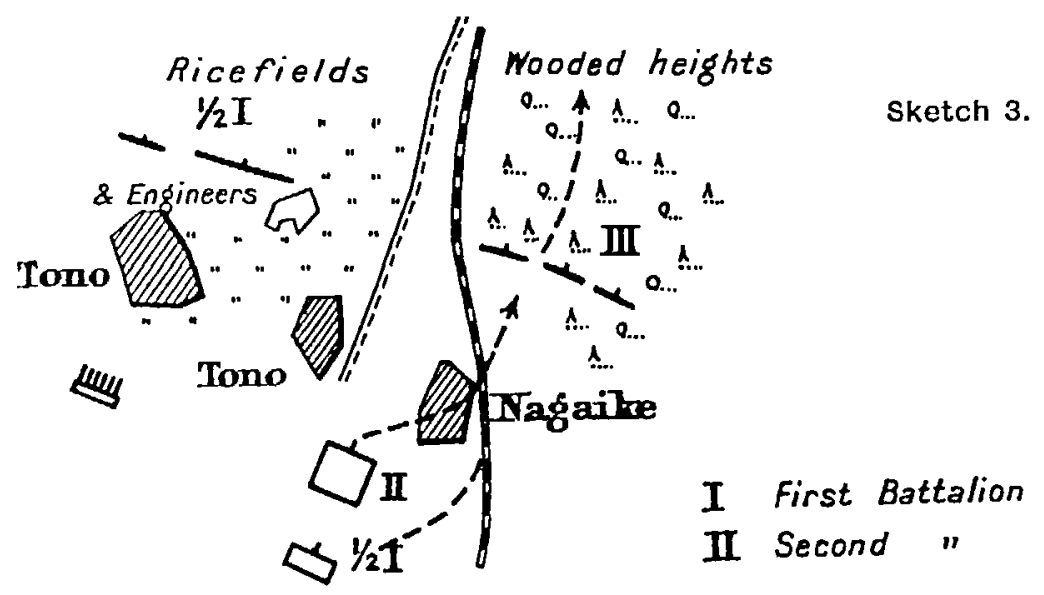

Too much weight was, however, attributed by Blue to the difficulties of crossing the somewhat swampy rice fields between Tono and Terada. As a result the frontal attack was not sufficiently pressed home, while a wide outflanking mancuvre through woods and mountains to the eastward was undertaken by a force of ten companies. This manœuvre did not long remain unperceived by Red, who left two companies and two machine-guns in the eastern portion of his entrenched position and employed the whole of the remainder (ten companies of infantry and one of pioneers) in a vigorous offensive west of the railway, the machine-guns advancing along the railway embankment itself.

Two or three Blue companies attempted a counter-attack out of the wood, but, taken as a whole, the Blue force had obviously got out of control in the wood, while, on the other hand, the Red attack was seen to be so well combined, and to be making such good progress across the rice fields and railway track that its success appeared beyond doubt both to umpires and spectators. 
I myself accompanied this attack on foot through the rice fields; at one moment we marched comfortably along dykes or over frozen places, at the next moment we sank waist deep; the dash and endurance displayed by the troops in this advance was beyond all praise. ${ }^{1}$

At the close of the manouvres the troops were still fresh though they had not had their clothes off for four days. Not a single man had fallen out from the Igth Infantry Regiment, and only a very small number from the other units.

Operations had ceased at 9 a.m. The conference, which was long and exhaustive, was held on the dyke of Terada, in the Red position, at a point where a good view was obtainable; it was concluded by i i a.m.

The Igth Infantry Regiment returned by rail to Tsuruga, arriving at II.30 p.m.; the remaining units returned to their stations by march route. The troops from Fushimi had to march ten miles; the 9th Regiment from Otsu, 14 miles; the 53rd Regiment from Nara, 12 miles.

\section{THE DIRECTOR'S CRITICISMS.}

A few of the most important points in the Director's criticism are given below :-

As regards the first day's operations the Director criticized (a) the employment of the mounted troops as "Independent Cavalry," a rôle for which they were numerically far too weak; (b) the dispersion of the troops, on both sides, during the advance, and (c) the notion apparently entertained by the artillery that they should only come into action when definite targets were visible.

As regards the events of the $13^{\text {th }}$ February he spoke somewhat as follows :-

"The retirement of Blue on this day was well executed, but detachments should have been left in front of the position, for security; some such detachments were left, it is true, but they withdrew quickly on to the position itself.

"If your intention at the moment is, not to strike a decisive blow, but to fight for time in which to strengthen your position. you must leave a screen of small detachments out in front, towards the enemy; these detachments must establish themselves at suitable points and keep off, or at any rate impede the enemy's reconnoitring parties. There is, of course, one drawback to the use of these detachments; they may become advanced positions; but in mountain country like this that is a matter of no importance.

1 For Director's criticisms on this day's operations see page 6o.-Ed 
"The Red side did not pursue with sufficient energy; they should have used their whole force, instead of employing isolated detachments. If Red had pressed the retirement vigorously Blue might have had great difficulty in reaching his position in the hills.

"In defensive positions in mountain country the question of fire at close ranges must be given the first place; fire at long ranges is of far less importance, because the enemy will nearly always be able to get out of it in a short time."

The preparations made, by Red, during the night, for the attack on the morning of the I $4^{\text {th }}$ were completely approvcd by the Director, who rightly attributed the successful execution of these movements-in spite of all the difficulties of the terrain - to the thoroughness of the training which the troops had received.

On the other hand, some fault was found with the handling, on the same day, of the Blue reserve, on the ground that it was not used as a whole for a counter-attack, but was employed to reinforce the front at various points.

The further steps taken by both sides on the 14th (i.e., the retirement of Red across the Kizu, and the pursuit by Blue as far as that river) were approved by the Director. His remarks on the last day's operations are sufficiently interesting to justify me in giving the principal points verbatim.

"On the afternoon of the 14 th the Red commander found himself compelled by the general situation and by the nature ot the ground near Terada to act on the defensive. But, although the position was strong for defence and the tactical situation might have been thought to prescribe a purely passive attitude, the possibility of an active defence was by no means excluded. Our New Japanese Infantry Training inculcates the importance of being always on the watch for opportunities of taking the offensive, or of delivering a counter-attack, even during the most passive phases of a defensive action.

"In this case such an opportunity was afforded by the woods east of the road; it was therefore a better plan to fix bayonets for wood fighting than to construct any number of trenches and wire entanglements. In wood fighting, as in night operations, events move rapidly ; after a short or vigorous firefight the troops must charge with cold steel; similarly provision must be made for launching a counter-attack.

"The Blue attack on the last day was a failure. If you throw troops into a wood they are soon swallowed up in it and control is lost; the Blue commander only kept two companies at his own disposal, the whole of the remainder had been thrown into the wood.

"If the intention was to attack through the wood the enemy should have been engaged by at least one battalion on the 
front, Nagaike-Tono. I imagine that the reason for the plan of attack adopted was the belief that the rice fields were impassable; but infantry must be able to get over any kind of ground; certainly no ground which is capable of being traversed at all can be considered as affording protection merely by the difficulties which it presents."

In conclusion, the Director was able to testify with justifiable pride "That both officers and men had maintained their zeal, undaunted by the difficulties they had encountered, and had spared no exertions to render the manouvres a success."

\section{THE AUTHOR'S OBSERVATIONS ON JAPANESE TACTICS.}

The object, which was systematically pursued in these winter manouvres, had been to employ the troops under the most varied conditions and at all hours of the day and night.

The Japanese views on night operations, which are based on their experiences in the war, are, in the main, approved in our (German) army, and form the basis of the British instructions for night operations, and also of French military instructions on the subject. The Japanese instructions lay repeated stress on the importance of adapting all measures to the circumstances of the case; the dispositions should be such as to compel the enemy to cross the skyline " and show himself upright "; on the other hand, their own troops must stand up as seldom as possible.

Troops should keep a little way off roads unless the latter are required for purposes of movement; light backgrounds are to be avoided.

By systematic training of the men's hearing powers, frequent night operations, and inspection of individual units by night, the troops acquire a capacity for scouting in a noiseless, catlike manner, which makes the work of Japanese infantry patrols as interesting to watch as the movements of a fox approaching its prey. Instinct and technical training work hand in hand. On one occasion an attack, which was delivered at daybreak over difficult ground by six companies, advanced so swiftly and silently that some reserves, which were stationed only 200 yards away, were unable to come up in time to assist in the defence.

The most important lesson which I mastered during these winter exercises-a lesson of which I had learned something at the autumn manouvres, and even before them-was in connection with that most important question of tactics-extensions under fire.

The Japanese demonstrated with the blood of many of their race that their divisions were capable of occupying areas and extents of front in battle to which their European opponents 
would not venture to assign formations of less than an army corps; they have, therefore, come to assume both in the education of their officers and in the training of their troops that they can safely exceed, by a considerable margin, the extensions which are regarded as normal by their European instructors. We (Germans) may think they are wrong, but we must nevertheless assume that we shall be opposed on a front of $1,55^{\circ}$ yards of entrenched position by only four companies, four machine-guns, and six guns employed in dispersed sections; or, on a front of 3,850 to 4,400 yards on the flank of an army, by only one division, which would nevertheless offer a very serious resistance. We ought, therefore, especially in view of the great expenditure of ammunition entailed by the increased range of modern firearms, to consider the matter impartially, and revise our preconceived opinions; or else we shall have to admit that a foreign army is superior in moral and fighting value to our own. There is no middle course if we propose to continue our policy of giving the doctrine of the enveloping attack the foremost place in the training of our officers and men, and if we do not decide to adopt the doctrine of "penetration" as better suited to our dense manocuvre and battle formations. The envelopment of these thin widely extended fronts, occupied by troops of a fighting value equal to our own, would, as a rule, be impossible in practice.

The Japanese troops derive great help in carrying out this doctrine of wide extensions, not only from their moral and spirit of self-sacrifice, but also from their skill in making use of the ground and overcoming natural obstacles, and from their excellent training in close reconnaissance, as well as from their rapidity of movement, which greatly increases the value of the reserves. To these must be added their perfect mastery of the use of entrenching tools both in attack and defence, ${ }^{1}$ and the marvellous skill displayed, even by N.C.o.'s and men acting on their own initiative, in the application of field fortification.

There is also something of an artist's touch in the eye for ground, which enables the leaders to get the best value out of the use of field entrenchments, and in their capacity for passing, with lightning rapidity-undeterred by any consideration of the labour which has been expended-from an apparently passive and apathetic defensive to an offensive of the most vigorous and active character. In this they are greatly assisted by the capacity of their infantry battalions, regiments, and brigades for covering distances of as much as 4,400 yards at a run.

No labour expended on field works is considered as excessive, even if they are only likely to be required for a short time,

I In this connection it must not be forgotten that the Japanese have a liberal allowance of pioneers; each division has a pioncer battalion of three companies. 
or even when the men working on them are aware that they are merely intended to mislead the enemy.

In spite of some mistakes, such as must always occur, it could be seen that the science of field engineering was thoroughly mastered, understood and intelligently applied by all ranks down to the individual soldier. Indeed it was observable that, as regards skill, theoretical knowledge, and general method of setting to work, the individual Japanese soldier was better trained in field fortification than our own; the men were allowed considerable independence in the execution of details and in improvising makeshifts.

The following are a few of the characteristic points which came to my notice during the manœuvres :-

(a) Defensive works visible from a great distance are, as a rule, assumed by the attackers to be dummy trenches, and no fire is directed against them, in the first instance, until it beconıes evident, during the attack, that they are occupied. (All genuine works are tested beforehand, whenever possible, by the side which constructs them, to see if they blend well with their backgrounds, so that the real trenches are seldom visible from a distance).

(b) It is considered very unlikely that an attack at dawn will find the defenders in the same position as they were in when reconnoitred on the previous evening. By day, works with a wide field of fire are considered the best; by night, preference is given to those which compel the enemy to cross a skyline or to show himself against a light background.

(c) No one shrinks from the labour of constructing two or three lines of defence so as to allow for alternative positions in special circumstances (e.g., darkness, thick weather, etc.).

(d) Two or three hours, even in complete darkness, is considered long enough to make ground, which affords ordinary -facilities to the advance of an attack, practically impassable to the enemy; and this must be effected without letting the enemy lnow that there is any reason to modify the favourable reports received from his reconnoitring parties on the previous evening.

(e) As regards entrenchments, whether in attack or defence, one line of resistance is preferred; this line must, however, have salients and re-entrants, and contain gaps which are swept by fire from other points; it must present to the enemy's reconnoitring parties an inaccessible zone of greater or less width, in which the defenders' fire prohibits any closer view.

Bodies of troops on the march are, as a rule, masked, at a distance of 550 yards, on either flank, by a screen of infantry patrols; these patrols have to cover a great deal of ground.

$(f)$ When the enemy has made all preparations for a formal attack, and can be seen at nightfall entrenching and digging himself in, one should suspect a surprise attack will be 
delivered from a quite unexpected direction, most probably in some quarter-if such exists-where the difficulties of the terrain offer a deceptive guarantee of protection.

I have seen the Japanese infantry at work for a long time, but I have never yet seen the ground which they would fail to cross in the long run. The only reluctance they displayas a burnt child dreads the fire-is towards crossing open ground bare of cover. In such cases they prefer to go greater distances through marshes or forests.

(g) It is a mistake to suppose that entrenching imposes more labour on the troops, in the long run, than the attempt to dispense with it.

When the sentries, picquets, and detaclied posts have been made secure behind entrenchments and obstacles, it is possible to practise the most extreme economy of force among the troops in rear. The latter, as well as the staffs, in their well-concealed bivouacs, eat, bathe, rest, or carry on their work in complete tranquillity; communication by telephone, flag or lamp, is established with neighbouring bodies of troops and with headquarters, and supplies of the simplest, though most serviceable kind are issued in ample quantities. Troops were limited to the active service scale of luxuries, but these were made full use of ; practically no restrictions were placed on the utilization of the resources of the theatre of war.

Though these manœuvres took place in winter the greater part of the troops bivouacked on three successive days; I think I now understand the attitude of the Japanese towards bivouacking. They regard it, in all its various graduations from bivouacking proper to close billeting, as a natural incident of field warfare at any time of the year. They do not like itquite the reverse- but they treat it as an unavoidable necessity; they make themselves quite at home in their bivouacs; they wash, unpack their kits, complete deficiencies from the baggage, which comes up just as it would in war, rest themselves thoroughly, and renew their strength.

In our (German) army-to be quite candid-bivouacking is regarded rather as a pause betwcen two stages of the mancuvres, and not as an opportunity for a thorough rest; this is not looked for till the next rest-day in billets, upon which we are, in consequence, unduly dependent.

The most brilliant achievement during these exercises was the fording of the Kizu River; this river seemed to me to resemble the Lech in strength and velocity of current, while the volume of water on the day in question was like that of the Alz; the water was covered with ice, except in places where the strength of the current prevented it from freezing.

The stream was piled up to such an extent by the passage of the artillery that the waves broke over the guns; the gun 
leaders were harnessed in a simple and practical manner, and the driving was good and careful all the way across. At some places the infantry had to wade breast deep through the foaming current; at these places the men linked arms, chiefly as a precaution against the giddiness to which some individuals are liable at the sight of swiftly flowing water.

The dismounted company commanders of the infantry had to wade, as did also the medicat officers, pay officers, etc. Some mounted officers also waded through out of zeal. Fighting went on after the crossing was over, until the tactical situation allowed an opportunity for the men to dry themselves and change their underclothing, after which they went on outpost duty or into bivouac:

The employment of dismounted company commanders- a plan adopted by Napoleon-appeared to me, in the light of these manceuvres, as a severe but eminently sound arrangement; it serves to bring out the hardiest and fittest infantry officers, and in cases (such as in pioneer battalions in this country) where there are six or eight horses available on the battalion staff to mount the officers if necessary, the system appears to be open to no objections.

Very noticeable at these manœuvres was the active support given by the administrative authorities, as was also the interest displayed by all the schools. As early as the first issue of orders at Tamamizu we met the Head of the Administration (Regierungs präsident) of Kyoto, a very distinguished old gentleman speaking French and German fluently, who did not think it at all beneath his dignity to go on in advance with his councillors and officials and see that everything had been arranged for the troops. The Head of the District (Kreischef) and the official in charge of bridge construction (Flussbauchef) were present from 3.30 a.m:, on a bitterly cold morning, on the day we crossed the Kizu.

The schools followed the troops in the same way as is done at the autumn manœuvres, that is to say, each class devoted a complete day to following some military movement which was going on within reach. Everything that was happening was carefully and patiently explained to them; they were shown the field entrenchments, the bivouacs, etc.; they in their turn displayed the liveliest interest, which will not fail to bear fruit later on. The pupils of the Secondary School (Mittelschule) at Tono-Nagaike were also given leave to follow the exercises, and later to prepare a good reception for the Directing and Divisional Staffs at their billets.

I feel that I cannot conclude this report without some word of thanks to those through whose courtesy I was enabled to get so much pleasure and advantage from these manceuvres, and especially to the gallant commander of the division, whose kindness was unremitting, and whose uppermost thought was

VOL. LVII. 
that the guest of his army should see everything that was possible as far as was compatible with the interests of his country. The Director also showed me the greatest kindness, in spite of the numerous demands on his attention, and his assistants were equally attentive. All orders and instructions were conveyed to me as early as possible, and any information which I asked for was promptly given. The civilians, both officials and people, also displayed a cordiality towards the foreign guest which far surpassed what is customary in our own country on similar occasions.

Taken as a whole, these winter exercises, in spite of their modest scope, were the most instructive of any that I witnessed during my attachment in Japan. 


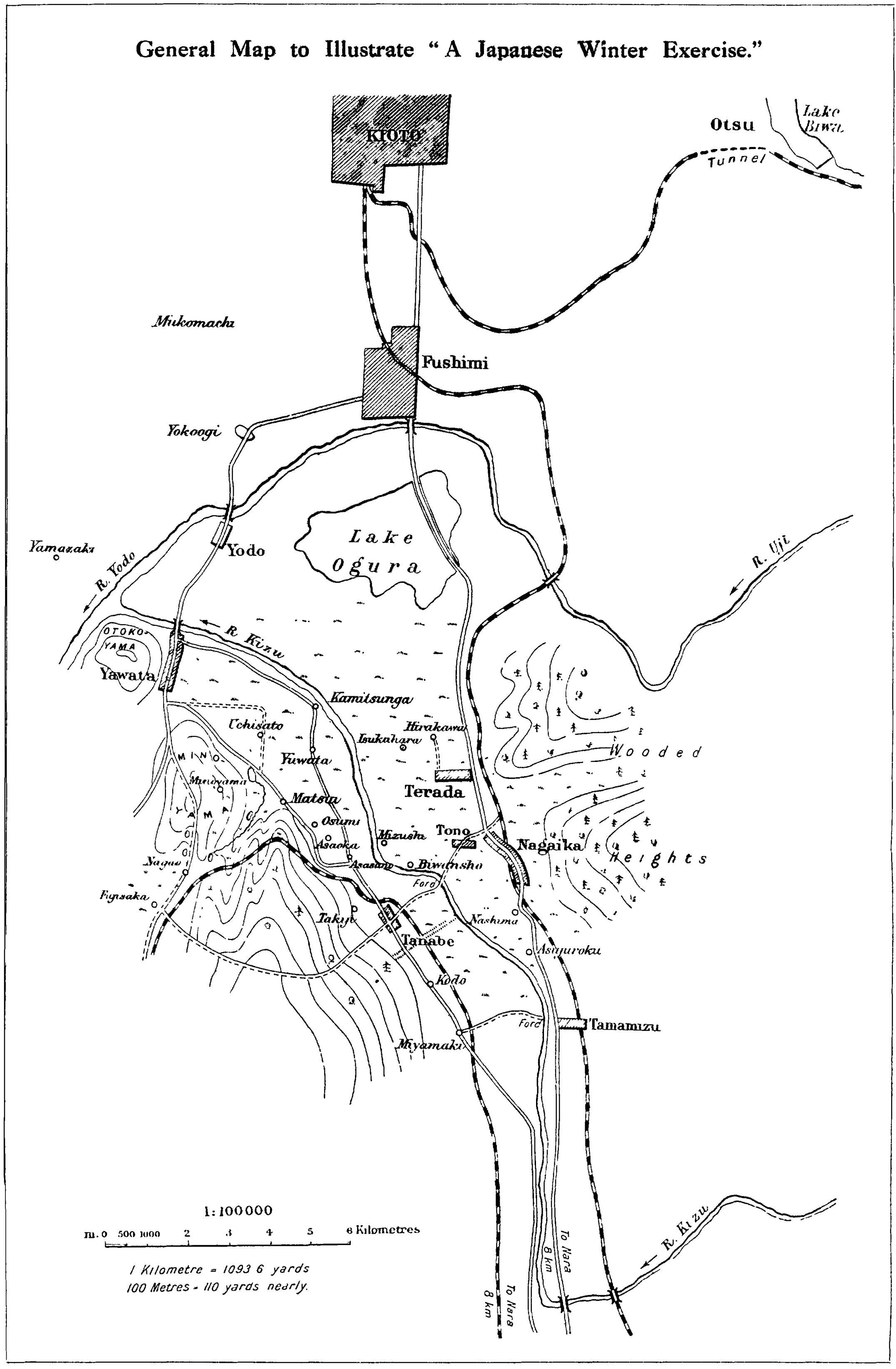

